\title{
Effects of Recombinant Human Growth Hormone on Muscle Protein Turnover in Malnourished Hemodialysis Patients
}

\author{
Giacomo Garibotto, ${ }^{*}$ Antonina Barreca, ${ }^{\ddagger}$ Rodolfo Russo, ${ }^{*}$ Antonella Sofia, ${ }^{*}$ Paolo Araghi, ${ }^{*}$ Arianna Cesarone, ${ }^{\ddagger}$ \\ Mauro Malaspina, ${ }^{\S}$ Fulvio Fiorini,, Francesco Minuto, ${ }^{\ddagger}$ and Alberto Tizianello* \\ *Division of Nephrology, Department of Internal Medicine, and ${ }^{\ddagger}$ Department of Endocrinology and Metabolism, University of Genoa, \\ Italy; and ${ }^{\S}$ Sampierdarena and ${ }^{\|}$Bussana Hospitals, 16132 Genoa, Italy
}

\begin{abstract}
To assess the effect of recombinant human growth hormone (rhGH) on muscle protein metabolism in uremic patients with malnutrition, forearm $\left[{ }^{3} \mathrm{H}\right]$ phenylalanine kinetics were evaluated in six chronically wasted (body weight $79 \%$ of ideal weight) hemodialysis (HD) patients in a self-controlled, crossover study. Forearm protein dynamics were evaluated before, after a 6-wk course of rhGH (5 mg thrice weekly) and after a 6-wk washout period. After rhGH: (a) forearm phenylalanine net balance- the difference between phenylalanine incorporation into and phenylalanine release from muscle proteins-decreased by $46 \%(-8 \pm 2$ vs. $-15 \pm 2$ $\mathrm{nmol} / \mathrm{min} \cdot 100 \mathrm{ml}$ at the baseline and $-11 \pm 2$ after washout, $P<0.02)$; (b) phenylalanine rate of disposal, an index of protein synthesis, increased by $25 \%(25 \pm 5$ vs. $20 \pm 5$ at the baseline and $20 \pm 4$ after washout, $P<0.03$ ); (c) phenylalanine rate of appearance, an index of protein degradation, was unchanged ( $33 \pm 5$ vs. $35 \pm 5$ at the baseline and $31 \pm 4$ after washout); $(d)$ forearm potassium release declined $(0.24 \pm 0.13$ vs. $0.60 \pm 0.15 \mu \mathrm{eq} / \mathrm{min}$ at the baseline, and $0.42 \pm 0.20 \mu \mathrm{eq} / \mathrm{min}$ after washout $P<0.03)$; $(e)$ changes in the insulin-like growth factor binding protein (IGFBP)-1 levels and insulin-like growth factor-I (IGF-I)/IGFBP-3 ratios accounted for $15.1 \%$ and $47.1 \%$ of the percent variations in forearm net phenylalanine balance, respectively. Together, these two factors accounted for $\mathbf{6 2 . 2 \%}$ of variations in forearm net phenylalanine balance during and after rhGH administration. These data indicate: $(a)$ that rhGH administration in malnourished hemodialysis patients is followed by an increase in muscle protein synthesis and by a decrease in the negative muscle protein balance observed in the postabsorptive state; and $(b)$ that the reduction in net protein catabolism obtained with rhGH can be accounted for by the associated changes in circulating free, but not total, IGF-I levels. (J. Clin. Invest. 1997. 99:97-105.) Key words: growth hormone $\cdot$ malnutrition $\bullet$ protein synthesis • potassium $\cdot$ hemodialysis
\end{abstract}

Portions of the data reported in this paper appeared in an abstract presented at the 29th Annual Meeting of the American Society of Nephrology, New Orleans, November 3-6, 1996.

Address correspondence to Giacomo Garibotto M.D., Department of Internal Medicine, Nephrology Division, University of Genoa, Viale Benedetto XV ${ }^{\circ}, 6,16132$ Genoa, Italy. Phone: 0039-103537970; FAX: 0039-10352324.

Received for publication 12 August 1996 and accepted in revised form 24 October 1996.

J. Clin. Invest.

(c) The American Society for Clinical Investigation, Inc.

0021-9738/97/01/0097/09 \$2.00

Volume 99, Number 1, January 1997, 97-105

\section{Introduction}

Malnutrition in patients with end-stage renal disease (ESRD) $)^{1}$ under hemodialytic treatment is closely correlated with poor clinical outcome (1). An inadequate protein-calorie intake, the increase in muscle protein degradation caused by metabolic acidosis (2-4), and the loss of amino acids during the dialytic procedure (5) are major causes of malnutrition. However, recent evidence indicates that chronic renal failure is also characterized by a resistance to anabolic hormones, such as growth hormone $(\mathrm{GH})$ and insulin-like growth factor-I (IGF-I). This resistance may in turn impair the control of growth in uremic children and protein metabolism in the adult population.

Animal studies performed both in vitro and in vivo indicate that resistance to the action of GH and IGF-I in uremia takes place in different sites, including both liver and muscle. In rats, experimental uremia leads to decreased expression of hepatic GH receptor mRNA $(6,7)$ and increases the circulating GH binding proteins, which in turn could potentially compete for ligand binding to GH receptors (7). These alterations could lead to a decreased IGF-I synthesis from endogenous or exogenously administered GH. In addition to these findings there is evidence of a resistance to GH and IGF-I occurring in uremic muscle. Indeed, a reduced IGF-I and IGF-I mRNA, and a decreased IGF-I receptor tyrosine kinase activity have been observed in muscle from uremic rats $(8,9)$.

In renal patients circulating levels of $\mathrm{GH}$ are increased, mainly as a consequence of a diminished metabolic and renal clearance $(10,11)$. In the same condition there is also evidence of an abnormal serum insulin-like growth factor binding proteins (IGFBPs) concentration, which can reduce IGF-I bioavailability (11). In hemodialysis (HD) patients, the volume of distribution of IGF-I after rhIGF-I injection is less than in the normal condition; this is consistent with the contention that IGF-I is retained in circulation by IGFBPs (12). It has also been documented that HD increases somatomedin bioactivity (13), thus suggesting the occurrence of low molecular weight circulating inhibitors of IGF-I action. In addition, the altered effects of GH and/or IGF-I due to uremia per se may be enhanced by a reduced protein/calorie intake (14).

Recombinant human GH (rhGH) promotes nitrogen retention and increases lean body mass in normal subjects (15) and in GH-deficient patients (16). The administration of rhGH also results in diminished sodium and potassium excretion, with accumulation of total body potassium (17). Treatment with rhGH is an established therapy in growth-retarded ure-

1. Abbreviations used in this paper: ESRD, end-stage renal disease; $\mathrm{GH}$, growth hormone; HD, hemodialysis; IGF-I, insulin-like growth factor-I; IGFBPs, insulin-like growth factor binding proteins; nPCR, normalized protein catabolic rate; rhGH, recombinant human growth hormone. 
mic children (18), but few studies have dealt with the effects of rhGH in adult renal patients. Short-term studies in malnourished HD patients have shown that the administration of rhGH alone or in combination with parenteral nutrition causes a reduction in urea appearance and an improvement in some biochemical nutritional parameters $(19,20)$ and nitrogen $(\mathrm{N})$ balance (21). The administration of rhGH for one week to peritoneal dialysis (CAPD) patients results in a decrease in urea generation (22). Such responses are associated with a decrease in plasma potassium, suggesting an incorporation of potassium into somatic proteins (22). However, it is not yet known whether rhGH administration in malnourished HD patients is followed by any action on the determinants of muscle mass, i.e., protein synthesis and degradation.

The present study was designed to determine the effects of rhGH on protein metabolism, amino acid exchange, and potassium balance in the muscle of nonacidotic HD patients with protein calorie malnutrition by using the forearm perfusion technique associated with $\left[{ }^{3} \mathrm{H}\right]$ phenylalanine infusion $(23,4)$. Changes in muscle protein dynamics were evaluated in relation to variations in circulating IGF-I and IGFBPs.

\section{Methods}

Patients. Six malnourished adult ambulatory HD patients (five males, one female; mean age $60 \pm 4 \mathrm{yr}$, range 39-68) on thrice weekly dialysis (mean dialytic age $5.5 \pm 2$. yr) participated in this study after informed written consent had been obtained. The causes of end-stage renal disease were: chronic glomerulonephritis (two patients), hypertension (two patients), interstitial nephritis (one patient), and lupus erythematosus (one patient). All subjects underwent initial screening, which included physical examination and nutritional assessment. All showed substantial evidence of malnutrition. Their body weight relative to ideal body weight (24) was 79 $\pm 3 \%$ (range 75-90\%); their arm muscle area and triceps skinfold thickness were in the $<5$ and $<10$ percentiles for normal adults of similar gender, age, height, and frame size $\left(33 \pm 3 \mathrm{~cm}^{2}\right.$ and $5.7 \pm 1 \mathrm{~mm}$, respectively). Serum albumin was $4.1 \pm 0.1 \mathrm{~g} / \mathrm{dl}, \mathrm{BUN} 88 \pm 4 \mathrm{mg} / \mathrm{dl}$, and lymphocyte count was $1334 \pm 200$ cells $/ \mathrm{mm}^{3}$. All patients had been adequately dialyzed $(\mathrm{Kt} / \mathrm{V}=$ $1.26 \pm 0.10)$. They had lost weight more than 6 mo before the study, during intercurrent illnesses and/or reduction of dietary intake. They had been clinically stable for at least 3 mo before the study, and in the $6 \mathrm{wk}$ of baseline follow-up. Patients had no history or evidence of gastrointestinal or hepatic disease, congestive heart failure, diabetes mellitus or other endocrinopathies, alcoholism, or malignancy. Residual renal function was $1.6 \pm 0.9 \mathrm{ml} / \mathrm{min}$. Their mean protein intake, as evaluated by the normalized protein catabolic rate (nPCr; 25), was $1.1 \pm 0.1 \mathrm{~g} / \mathrm{kg}$ (range $0.9-1.4 \mathrm{~g} / \mathrm{kg}$ ), and their calorie intake was about $28-31 \mathrm{kcal} / \mathrm{kg}$, as estimated by nutritional interviews. Dietary survey included a weekly 3 -d food record during each experimental period and PCR. No changes in dietary prescriptions or the intake of nutrients, as evaluated by nutritional interviews and $\mathrm{nPCR}$, were recorded during the study (nPCR $0.95 \pm 0.06$ after $\mathrm{rhGH}$ and $1.1 \pm 0.06 \mathrm{~g} / \mathrm{kg}$ in the washout period). The dose of dialysis was constant throughout the study $(\mathrm{Kt} / \mathrm{V}=1.26 \pm 0.10$ at the baseline, $1.22 \pm 0.11$ after $\mathrm{rhGH}$, and $1.24 \pm 0.12$ in the washout period). Acidemia, which can cause muscle protein degradation (2), was prevented in all phases of the study $\left[\mathrm{HCO}_{3}-\right]=24 \pm 1$ at the baseline, $25 \pm 2$ after $\mathrm{GH}$, and $24 \pm 2$ $\mathrm{meq} / \mathrm{liter}$ in the washout period). Drugs, including hypotensive drugs, sodium bicarbonate, calcium carbonate, and erythropoietin, which were prescribed as appropriate for each individual, were also continued.

This study was approved by the Ethical Committee of the Department of Internal Medicine of the University of Genoa. All patients were informed of the nature, purpose, procedure, and possible risks before their voluntary consent was obtained. Procedures were in accordance with the Helsinki declaration.

Study design. The study was a prospective crossover trial with patients serving as their own controls. The study consisted of three consecutive periods: the baseline period, the $\mathrm{GH}$ treatment period (GHTx), and the washout, post-GH period (follow-up; Fig. 1). During a 6-wk period before rhGH treatment, patients were instructed on a stable diet, and nutritional and dialysis parameters were evaluated. At the end of this period baseline measurements were obtained. In the treatment period, patients received $5 \mathrm{mg}$ rhGH (Genotropin; Pharmacia, Stockholm, Sweden) subcutaneously at the end of each dialysis session for $6 \mathrm{wk}$. Subsequently, rhGH was discontinued and patients were followed-up for a further $6 \mathrm{wk}$.

Forearm protein turnover studies were performed at the end of each study period (Fig. 1), namely at the beginning of the week, before the dialysis session, in order to avoid interference in protein turnover induced by dialytic treatment. In the $\mathrm{GH}$ period, the last dose of rhGH had been administered $72-74 \mathrm{~h}$ before the protein turnover study. Blood samples were also obtained for IGF-I, IGFBP-1, IGFBP-3, insulin, cortisol, and other serum chemistries at the end of each study period.

Procedures. The study of muscle protein turnover was performed in the postabsorptive, overnight fasted state. Each patient received a primed-continuous infusion of L-(ring 2,6)- $\left[{ }^{3} \mathrm{H}\right]$ phenylalanine $(\sim 11$ $\mu \mathrm{Ci}, 0.42 \mu \mathrm{Ci} / \mathrm{min}$ ) through a contralateral vein for $210 \mathrm{~min}$. Catheters were inserted into a brachial artery and, in a retrograde fashion, into the ipsilateral deep forearm vein. In one subject arterial sampling was performed by direct puncture of an arteriovenous graft extending from the contralateral radial artery to the basilic vein. In all studies in each patient, care was taken in order to catheterize the same vein in the same position. After a 150-min tracer equilibration period, blood samples were taken simultaneously from the artery and the vein at 20-min intervals during a 60-min period. Blood flow across the forearm was determined immediately after each arterio-venous sampling by an indium-gallium strain gauge plethysmograph (Angiomed Instruments, Padua, Italy). The arm containing the deep vein was raised about $20^{\circ}$ and a small supporting pillow was placed under the wrist, to avoid interference with venous return. The strain gauge was wrapped around the forearm at the level of maximal circumference. The relative change in the volume of the forearm segment under the strain gauge was registered and was used to calculate plethysmographic blood flow. An occlusion cuff was placed around the arm. The pressure was $60 \mathrm{mmHg}$. Each set of measurements involved 10 separate measurements $(\mathrm{CV}=3.5 \%)$. For $1 \mathrm{~min}$ before and during withdrawal of each blood sample, blood flow to the hand was interrupted by means of a sphygmomanometer cuff inflated around the wrist to 200 $\mathrm{mmHg}$. Flow was expressed per $100 \mathrm{ml}$ forearm volume. Room temperature was $20-22^{\circ} \mathrm{C}$.

Assays. Amino acids were determined in whole blood. Perchloric acid $(0.75 \mathrm{~mol} / \mathrm{liter})$ was used for blood protein precipitation. An aliquot of the supernate was neutralized with a buffered solution, stored at $-25^{\circ} \mathrm{C}$, and used for the assay of glutamine and glutamate. An-

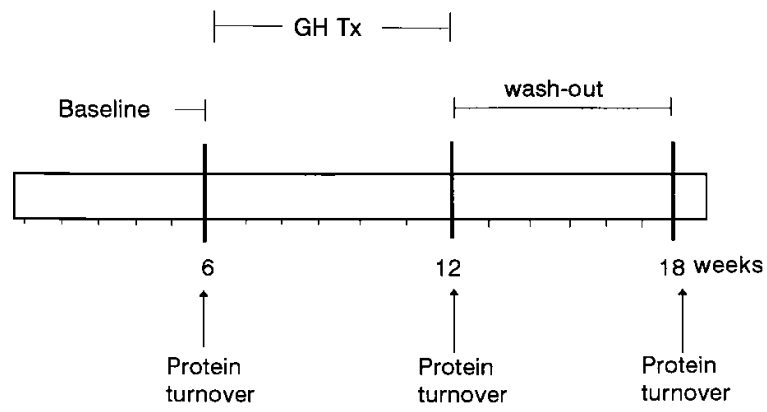

Figure 1. The design of the study. $5 \mathrm{mg}$ of rhGH was administered thrice weekly during the period of treatment. 
other aliquot was stored at $-25^{\circ} \mathrm{C}$ and used for the determination of other amino acids. Blood samples were processed immediately after withdrawal. Amino acids were measured in triplicate by an amino acid analyzer (model 3A 30; Fisons Instruments, Milan, Italy), employing lithium buffers. Glutamine and glutamate were determined enzymatically (26). Phenylalanine-specific activity was determined in plasma, as described previously (4). Arterio-venous differences for potassium were measured in plasma samples taken at intervals of 20 min each during the study. Plasma was immediately separated after withdrawal and measured in triplicate by flame photometry (model 480 Flame Photometer; Corning Medical and Scientific, Medfield, MA). Forearm potassium balance was obtained by multiplying the arterio-venous difference for potassium by plasma blood flow. Forearm plasma flow was estimated from measured blood flow by the equation: plasma flow $=$ (blood flow $) \times(1-$ hematocrit $)$.

Concentrations of IGF-I and IGF binding proteins, insulin and cortisol were measured at the end of each study period. IGF-I was measured by RIA using an antibody and ${ }^{125}$ I-IGF-I provided by Medgenix (Fleurus, Belgium). The sensitivity of the assay was $90 \mathrm{pg} /$ $\mathrm{ml}$ and the interassay assay coefficient of variation was $7.7 \%$. No cross-reactivity could be evidenced between IGF-I and IGF- 2 with the respective antibodies used in the assays up to concentrations of $500 \mathrm{ng} / \mathrm{ml}$ of both peptides. In order to avoid interference from binding proteins, single plasma EDTA samples taken from each patient before and during treatment were treated with acid ethanol, according to Daughaday (27). IGFBP-1 was measured by IRMA using reagents and tracer provided by Diagnostic Systems Laboratories, Inc. (Webster, TX). Normal ranges for IGF-I and IGFBP-1 in agematched adult subjects are $100-350 \mathrm{ng} / \mathrm{ml}$ and $20-40 \mu \mathrm{g} / \mathrm{liter}$, respectively. IGFBP-3 was measured by immunoassay using reagents and tracer (Diagnostic Systems Laboratories, Inc.). All samples were diluted appropriately so as to reach a point in the curve where there is parallelism among unglycosylated Escherichia coli-derived IGFBP-3, glycosylated CHO-derived IGFBP-3, and serum (\% B/Bo: 70-85\%). According to the manufacturer, the normal range for age-matched adult subjects is $2.10-5.01 \mu \mathrm{g} / \mathrm{ml}$. Plasma insulin and cortisol were determined by radioimmunoassay (Diagnostic Products Corp., Los Angeles, CA, and Farmos, Orion Corporation, Turku, Finland, respectively). Arterial blood $\mathrm{pH}$ and $\mathrm{pCO}_{2}$ were estimated at $37^{\circ} \mathrm{C}$ with an ABL 505 apparatus (Radiometer Co., Copenhagen, Denmark). Blood bicarbonate concentrations were calculated by using the Henderson-Hasselbalch equation. Hematocrit was measured by a microcapillary procedure. All other serum chemical measurements were determined by routine clinical chemistry laboratory procedures.

Calculations. The net forearm balance for amino acids was calculated from the Fick principle: net balance $=([\mathrm{A}]-[\mathrm{V}]) \times$ blood flow, where $[\mathrm{A}]$ and $[\mathrm{V}]$ are the arterial and venous concentrations, respectively. Phenylalanine is not metabolized in muscle, thus the rates of disposal of phenylalanine across the forearm in the steady state reflect its rates of incorporation into protein, while tissue rates of appearance of phenylalanine reflect its release from tissue protein breakdown (23). Net balance expresses the difference between the rate of disposal of arterial phenylalanine $(\mathrm{Rd})$ and the rate of appearance into veins of phenylalanine $(\mathrm{Ra})$, i.e.: net balance $=\mathrm{Rd}-\mathrm{Ra}$. In the postabsorptive condition, as evaluated in the present study, the net balance of phenylalanine across the forearm is negative and expresses net proteolysis.

Phenylalanine $\mathrm{Ra}$ was calculated as follows $(23,4): \mathrm{Ra}=$ blood flow $\times[\mathrm{V}] \times(1-\mathrm{SAv} / \mathrm{SAa})$, where $[\mathrm{V}]$ is the venous blood level of phenylalanine, and SAa and SAv indicate the specific activity $(\mathrm{dpm} /$ nmol) of phenylalanine in the artery and vein, respectively. The term $(1-\mathrm{SAv} / \mathrm{SAa})$ expresses the dilution of tracer specific activity across the forearm caused unlabeled phenylalanine released by muscle.

Muscle disposal of unlabeled phenylalanine (Rd) was calculated as follows: $\mathrm{Rd}=\mathrm{Ra}+$ net balance. Whole body phenylalanine flux was calculated from the rate of tracer infusion $(\mathrm{dpm} / \mathrm{min})$ divided by the $\left[{ }^{3} \mathrm{H}\right]$ phenylalanine specific activity in arterial blood (23).
Statistical analysis. All data are presented as the mean \pm SEM. Statistical analysis was performed using the two-tailed $t$ test to compare arterial with venous data. When the arterio-venous difference was different from $0(P<0.05)$, or when intragroup statistical significances were to be evaluated, a repeated-measure analysis of variance was used to compare the overall changes during the three phases of the study. When ANOVA indicated statistical significance $(P<0.05)$, a post-hoc F-based test was performed between phases. To establish the differences in amino acid concentrations between patients and controls, the unpaired $t$ test and one-way analysis of variance followed by post-hoc analysis were used. Linear regression and correlation were employed to evaluate the relationship between two variables. Stepwise multiple regression analysis was used in order to discover which independent variables were significantly related to the dependent variables when the contribution of other independent variables was factored out and to discover what proportion of variations in dependent variables was accounted for by each independent variable and by the model. Statistical analysis was performed with the Statview Statistical Package (Abacus Concepts, Inc., Berkeley, CA).

\section{Results}

Hormones, substrates, and phenylalanine kinetics across the forearm. Results regarding serum hormones, IGFPBs, and phenylalanine levels are shown in Table I. Basal serum IGF-I and IGFBP-3 were in the normal range. IGFBP-1 levels were increased about six- to sevenfold over normal values. Serum insulin and cortisol were normal. Serum IGF-I and IGFBP-3 increased significantly (by 36 and $26 \%$, respectively) with treatment, and declined in the washout period. IGFBP-1 declined by $38 \%$ with treatment and rose in the washout period. There was no change in serum insulin or cortisol.

No differences from basal levels were detected in forearm blood flow during and after rhGH treatment. RhGH therapy was not associated with changes in phenylalanine concentrations in either the artery or vein. In the basal study, as well as in following periods, the deep venous phenylalanine levels ex-

Table I. Serum Hormone and Insulin-like Growth Factors Binding Proteins (IGFBPs) Levels, Forearm Blood Flow, Phenylalanine Levels in Arterial and Deep Venous Blood, and Phenylalanine Arterio-Venous Difference at the Baseline, during and after GH Treatment in Malnourished Hemodialysis Patients

\begin{tabular}{lccc}
\hline & Baseline & GH treatment & Washout \\
\hline IGF-1 $(\mathrm{ng} / \mathrm{ml})$ & $204 \pm 20$ & $277 \pm 20^{*}$ & $226 \pm 30$ \\
IGFBP-1 $(\mu \mathrm{g} / \mathrm{liter})$ & $266 \pm 41$ & $166 \pm 27^{*}$ & $248 \pm 38$ \\
IGFBP-3 $(\mu \mathrm{g} / \mathrm{ml})$ & $3.71 \pm 0.26$ & $4.67 \pm 0.38^{\ddagger}$ & $3.89 \pm 0.36$ \\
Insulin $(\mu \mathrm{U} / \mathrm{ml})$ & $7.2 \pm 0.51$ & $9.4 \pm 1.49$ & $8.2 \pm 0.95$ \\
$\quad \begin{array}{c}\text { Cortisol }(\mathrm{nmol} / \mathrm{liter}) \\
\text { Forearm blood flow }\end{array}$ & $178 \pm 19$ & $189 \pm 28$ & $185 \pm 27$ \\
$\quad(\mathrm{ml} / \mathrm{min} \cdot 100 \mathrm{ml})$ & $3.8 \pm 0.79$ & $3.3 \pm 0.43$ & $3.3 \pm 0.31$ \\
$\begin{array}{l}\text { Arterial phenylalanine } \\
\quad(\mathrm{nmol} / \mathrm{ml})\end{array}$ & $42.6 \pm 2.34$ & $42.4 \pm 2.78$ & $42.2 \pm 2.40$ \\
$\begin{array}{l}\text { Venous phenylalanine } \\
\quad(\mathrm{nmol} / \mathrm{ml})\end{array}$ & $47.4 \pm 2.74$ & $45.1 \pm 3.02$ & $45.8 \pm 2.90$ \\
$\begin{array}{l}\text { Phe A-V difference } \\
\quad(\mathrm{nmol} / \mathrm{ml})\end{array}$ & $-4.7 \pm 0.9^{\S}$ & $-2.7 \pm 0.69 * \|$ & $-3.6 \pm 0.53^{\S}$ \\
\end{tabular}

Significance of difference from the corresponding value at the baseline: ${ }^{*} P<0.02$ or less; ${ }^{\ddagger} P<0.05$. Probability that $\mathrm{A}-\mathrm{V}$ difference does not differ from $0:{ }^{\S} P<0.005$ or less; $\| P<0.01$. 


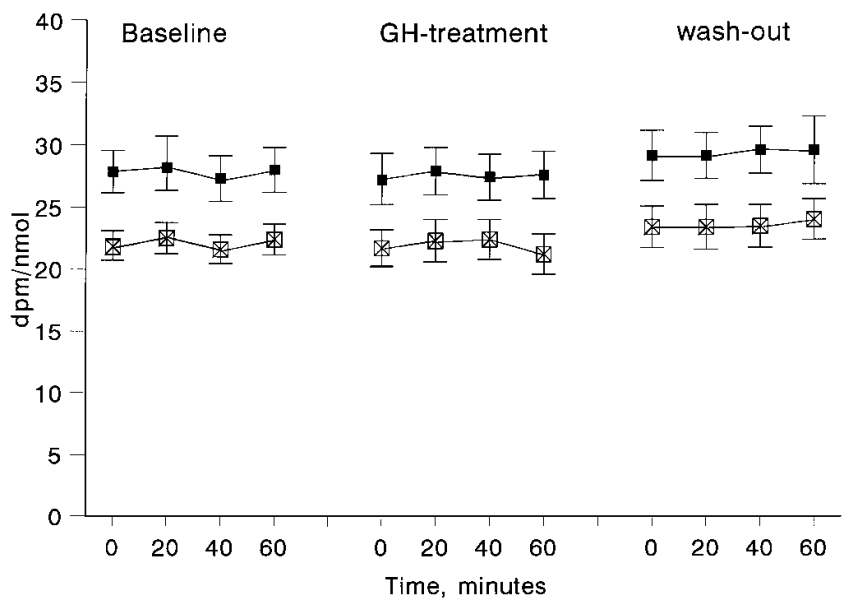

Figure 2. Plasma ${ }^{3}[\mathrm{H}]$ phenylalanine specific activity in the artery and deep forearm vein $(\otimes)$ during the three phases of the study.

ceeded the arterial levels $(P<0.01)$, thus indicating phenylalanine release from the forearm and proteolysis. However, during rhGH treatment the arterio-venous differences of phenylalanine were $44 \%$ smaller than in the baseline period $(P<$ $0.03)$.

During the three experimental periods the $\left[{ }^{3} \mathrm{H}\right]$ phenylalanine-specific activities were stable in the artery and the vein (Fig. 2). Specific activities in venous blood were lower than in arterial blood, indicating isotope dilution across the forearm and phenylalanine release $(P<0.01)$. Phenylalanine specific activities in the artery and in the vein were similar in all periods of the study.

Data regarding forearm protein turnover are shown in Table II. At the baseline the rate of appearance of phenylalanine from the forearm exceeded the rate of disposal, thus indicating a negative protein balance. At the end of the rhGH treatment period a negative protein balance persisted across the forearm; however, the net phenylalanine release was $46 \%$ lower, indicating a less negative balance than in the baseline period. This occurred because of a $25 \%$ increase in the phenylalanine rate of disposal, while the rate of appearance was not affected by treatment.

Whole-body phenylalanine flux, an index of whole-body proteolysis, was not affected by treatment $(0.73 \pm 0.075,0.78 \pm$ 0.091 , and $0.69 \pm 0.075 \mu \mathrm{mol} / \mathrm{kg} / \mathrm{min}$, respectively, in the baseline, $\mathrm{rhGH}$, and washout periods, $P=\mathrm{NS}$ ).

There was no relationship between the rates of protein synthesis or degradation and serum levels of IGF-I, IGFBP-1,

Table II. Rates of Appearance and Disposal and

Phenylalanine Net Balance Across the Forearm in Six Malnourished Hemodialysis Patients at the Baseline, during the GH Treatment Period (GH-Tx) and in the Washout, Post-GH Period (Washout) (nmol/min.100 ml)

\begin{tabular}{lrcr}
\hline & Baseline & GH-Tx & Washout \\
\hline Rate of appearance & $35 \pm 5$ & $33 \pm 5$ & $31 \pm 4$ \\
Rate of disposal & $20 \pm 5$ & $25 \pm 5^{*}$ & $20 \pm 6$ \\
Net balance & $-15 \pm 2$ & $-8 \pm 2^{\ddagger}$ & $-11 \pm 2$ \\
\end{tabular}

Significance vs. baseline: ${ }^{*} P<0.03 ;{ }^{\ddagger} P<0.01$.

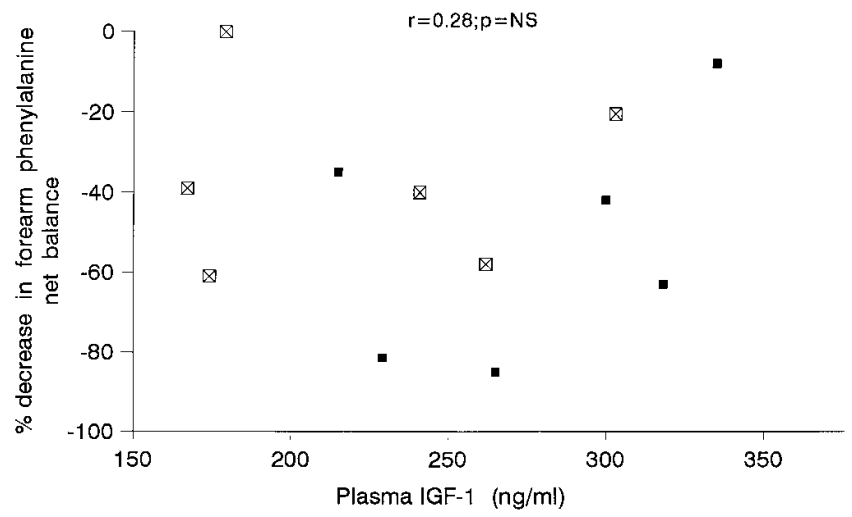

Figure 3. The percent decrease over basal values in forearm phenylalanine net balance vs. serum IGF-I in malnourished HD patients in the postabsorptive state during $(\mathbf{\square})$ and after rhGH administration $(\bigotimes)$. There was no relationship between these parameters.

IGFBP-3, insulin, cortisol or total or normalized to body weight rhGH dose. Nor was there any relationship between net forearm phenylalanine balance and serum IGF-I (Fig. 3). However, both in the rhGH and washout periods, the percent decrease in forearm net phenylalanine balance was directly related to serum IGFBP-1 levels (Fig. 4): the higher the circulating level of IGFBP-1, the lower the percent reduction in forearm phenylalanine output. Moreover, the percent decrease in forearm net phenylalanine balance was inversely related to the percent increase in the IGF-I/IGFBP-3 ratio (Fig. 5): the higher this ratio, the higher was the percent decrease in forearm phenylalanine output.

Stepwise multiple regression analysis was used in order to discover what proportion of variations in net protein balance (dependent variable) was accounted for by IGF-I/IGFBP-3 ratio and IGFBP-1 levels (independent variables), which were significantly related in simple regression analysis (Table III). Changes in the IGF-I/IGFBP-3 ratios and IGFBP-1 levels accounted for $47.1 \%$ and $15.1 \%$ of percent variations in forearm net phenylalanine balance, respectively. Together, these two

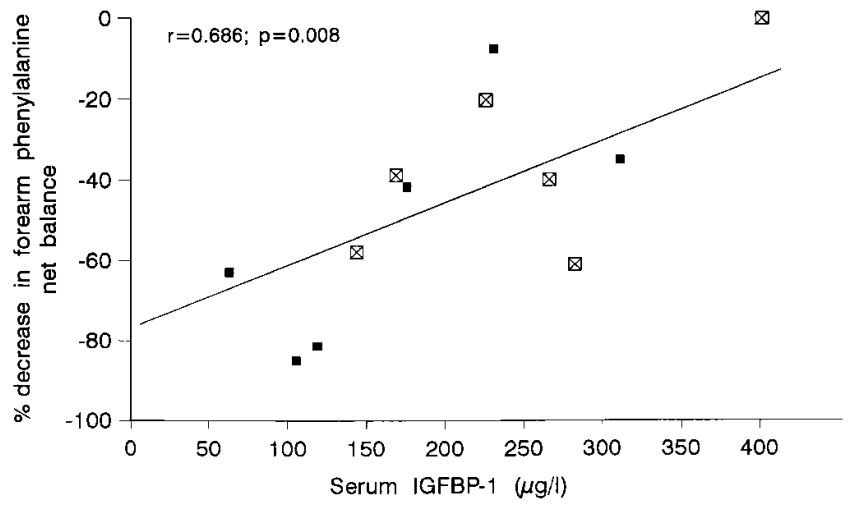

Figure 4. The percent decrease over basal values in forearm phenylalanine net balance vs. serum IGFBP-1 during (ם) and after rhGH administration $(\bigotimes)$ in malnourished HD patients in the postabsorptive state. The decrease in forearm phenylalanine net balance was directly correlated with serum IGFBP-1 levels, with greatest decreases observed with low circulating IGFBP-1. 
Table III. Determinants of Percent Variations in Forearm Phenylalanine Net Balance during and after rhGH by Using Stepwise Multiple Regression Analysis

\begin{tabular}{lcccc}
\hline Variable & $\begin{array}{c}\text { Sign of the } \\
\text { regression coefficient }\end{array}$ & Partial r2 & $P$ & Model r2 \\
\hline IGF-I/IGFBP-3 ratio* & - & 0.471 & $<0.05$ & - \\
Serum IGFBP-1 & + & 0.151 & $<0.05$ & $0.622<$ \\
\hline
\end{tabular}

*IGF-I/IGFBP-3 ratio was expressed as percent variations over baseline levels. Together, IGF-I/IGFBP-3 ratio and serum IGFBP-1 accounted for $62.2 \%$ of variations in forearm net phenylalanine balance during and after rhGH administration.

factors accounted for $62.2 \%$ of variations in forearm net phenylalanine balance during and after rhGH administration.

During GH treatment there was an increase in arm muscle area $\left(34.3 \pm 3\right.$ vs. $32.6 \pm 3 \mathrm{~cm}^{2}$ in the basal period and $33.8 \pm 3$ $\mathrm{cm}^{2}$ in the post-GH period, $\left.P<0.03\right)$ and in the estimated dry weight $(52.9 \pm 3$ vs $52.2 \pm 3 \mathrm{~kg}$ in the basal period and $52.4 \pm 3$ in the post-GH period; $P<0.05$ ). Values for skinfolds measurements (sum of four skinfolds, i.e., bicipital, tricipital, subscapular, and thoracic lateral) showed a tendency towards a decrease $(17.2 \pm 1.9 \mathrm{~mm}$ in the $\mathrm{GH}$ period vs. $18.3 \pm 2.2 \mathrm{~mm}$ in the basal state, and $16.9 \pm 1.8 \mathrm{~mm}$ in the post-GH period; $P=\mathrm{NS}$ ).

Amino acid balance across the forearm. Arterial levels of amino acids in patients were compared with those obtained in 35 normal subjects (25 males and 10 females) (28). The HD patients with protein-calorie malnutrition studied here showed lower arterial levels of serine, valine, leucine, tyrosine, lysine, and total essential amino acids, and higher levels of proline, citrulline, histidine, and cyst(e)ine as compared to normal con- trols (Table IV). During rhGH treatment there was no overall change in amino acids levels. As for individual amino acids, only cyst(e)ine significantly declined, while glutamate increased. Both amino acids returned to pretreatment levels after $\mathrm{GH}$ discontinuation.

During rhGH treatment, total amino acids released from the forearm decreased significantly. The net output of several amino acids, such as threonine, serine, glutamine, valine, isoleucine, leucine, lysine, and histidine, which was observed in the basal period, was no longer evident after rhGH. No statistical differences in the release of alanine were observed. After rhGH cyst(e)ine was significantly taken up from the forearm; moreover rhGH treatment was followed by an increase in the fractional extraction of this amino acid from the forearm $(6.97 \pm 1$ vs. $1.6 \pm 0.73$ at the baseline and $4.2 \pm 1.5$ in the washout period; $P<0.05)$.

Potassium balance across the forearm. In the baseline period, all patients showed a negative potassium balance across

Table IV. Arterial Concentrations and Forearm Exchange of Amino Acids (AA) before, during, and after GH Treatment in Malnourished Hemodialysis Patients

\begin{tabular}{|c|c|c|c|c|c|c|}
\hline & \multicolumn{2}{|c|}{ Baseline } & \multicolumn{2}{|c|}{ After GH Tx } & \multicolumn{2}{|c|}{ Washout } \\
\hline & $\begin{array}{c}\text { Arterial } \\
\text { concentration }\end{array}$ & $\begin{array}{l}\text { Forearm } \\
\text { exchange }\end{array}$ & $\begin{array}{c}\text { Arterial } \\
\text { concentration }\end{array}$ & $\begin{array}{l}\text { Forearm } \\
\text { exchange }\end{array}$ & $\begin{array}{c}\text { Arterial } \\
\text { concentration }\end{array}$ & $\begin{array}{l}\text { Forearm } \\
\text { exchange }\end{array}$ \\
\hline & $\mathrm{nmol} / \mathrm{ml}$ & $\mathrm{nmol} / \mathrm{min} \cdot 100 \mathrm{ml}$ & $\mathrm{nmol} / \mathrm{ml}$ & $\mathrm{nmol} / \mathrm{min} \cdot 100 \mathrm{ml}$ & $\mathrm{nmol} / \mathrm{ml}$ & $\mathrm{nmol} / \mathrm{min} \cdot 100 \mathrm{ml}$ \\
\hline Taurine & $191 \pm 16$ & $-8 \pm 7$ & $244 \pm 30$ & $+26 \pm 10$ & $202 \pm 15$ & $5 \pm 8$ \\
\hline Threonine & $88 \pm 6$ & $-38 \pm 13^{\|}$ & $89 \pm 8$ & $-5 \pm 8$ & $100 \pm 14$ & $-19 \pm 5^{*}$ \\
\hline Serine & $80 \pm 7 *$ & $-13 \pm 4^{\S}$ & $86 \pm 7$ & $+6 \pm 6$ & $86 \pm 10$ & $-4 \pm 3$ \\
\hline Glutamate & $142 \pm 22$ & $+42 \pm 4^{\|}$ & $167 \pm 6^{* *}$ & $+77 \pm 16^{\|}$ & $145 \pm 9$ & $+66 \pm 12^{\|}$ \\
\hline Glutamine & $424 \pm 26$ & $-80 \pm 9 \|$ & $409 \pm 23$ & $-20 \pm 29$ & $438 \pm 17$ & $-65 \pm 10^{\|}$ \\
\hline Proline & $244 \pm 27^{\ddagger}$ & $-3 \pm 2$ & $265 \pm 38$ & $+2 \pm 2$ & $277 \pm 38$ & $-6 \pm 4$ \\
\hline Glycine & $276 \pm 43$ & $-48 \pm 8^{\|}$ & $295 \pm 33$ & $-8 \pm 11$ & $274 \pm 28$ & $-18 \pm 11$ \\
\hline Alanine & $218 \pm 20$ & $-154 \pm 14 \|$ & $283 \pm 40$ & $-119 \pm 13^{\|}$ & $226 \pm 18$ & $-132 \pm 18^{\|}$ \\
\hline Citrulline & $84 \pm 10^{\ddagger}$ & $+4 \pm 2$ & $84 \pm 7$ & $+13 \pm 5$ & $93 \pm 10$ & $+11 \pm 5$ \\
\hline Valine & $109 \pm 10^{\ddagger}$ & $-23 \pm 4 \|$ & $118 \pm 12$ & $-3 \pm 5$ & $123 \pm 10$ & $-4 \pm 8$ \\
\hline Cyst(e)ine & $112 \pm 15^{\ddagger}$ & $+7 \pm 4$ & $100 \pm 11^{\text {I }}$ & $+27 \pm 7^{\|}$ & $115 \pm 15$ & $+17 \pm 8$ \\
\hline Isoleucine & $43 \pm 3$ & $-9 \pm 2 \|$ & $43 \pm 6$ & $0 \pm 3$ & $40 \pm 2$ & $-6 \pm 2^{\S}$ \\
\hline Leucine & $71 \pm 6^{*}$ & $-22 \pm 3^{\|}$ & $70 \pm 7$ & $-9 \pm 5$ & $75 \pm 5$ & $-10 \pm 5^{\S}$ \\
\hline Tyrosine & $33 \pm 3^{*}$ & $-11 \pm 1^{\|}$ & $36 \pm 4$ & $-6 \pm 2^{\|\|}$ & $35 \pm 2$ & $-9 \pm 3^{\S}$ \\
\hline Ornithine & $76 \pm 4$ & $-7 \pm 3$ & $77 \pm 5$ & $+5 \pm 6$ & $87 \pm 6$ & $4 \pm 7$ \\
\hline Lysine & $122 \pm 7 *$ & $-31 \pm 5^{\|}$ & $119 \pm 11$ & $-11 \pm 6$ & $137 \pm 6$ & $-21 \pm 10^{\S}$ \\
\hline Histidine & $74 \pm 6^{*}$ & $-14 \pm 3^{\S}$ & $80 \pm 7$ & $-4 \pm 4$ & $80 \pm 5$ & $-7 \pm 6$ \\
\hline Arginine & $62 \pm 6$ & $-17 \pm 2^{\|}$ & $58 \pm 4$ & $-9 \pm 2^{\|}$ & $64 \pm 6$ & $-12 \pm 2^{\|}$ \\
\hline Total AA & $2449 \pm 125$ & $-475 \pm 56$ & $2623 \pm 134$ & $-205 \pm 80^{\S \pi}$ & $2597 \pm 123$ & $-346 \pm 63 \|$ \\
\hline
\end{tabular}

Significance of difference from the arterial concentration of AA in 35 normal subjects (see Methods): $* P<0.05$; ${ }^{\ddagger} P<0.025$ or less. Probability that A - V differences do not differ from $0:{ }^{\S} P<0.05,{ }^{\|} P<0.025$ or less. Statistically different from baseline: ${ }^{\mathbb{I}} P<0.05 ; * * P<0.01$ or less. 


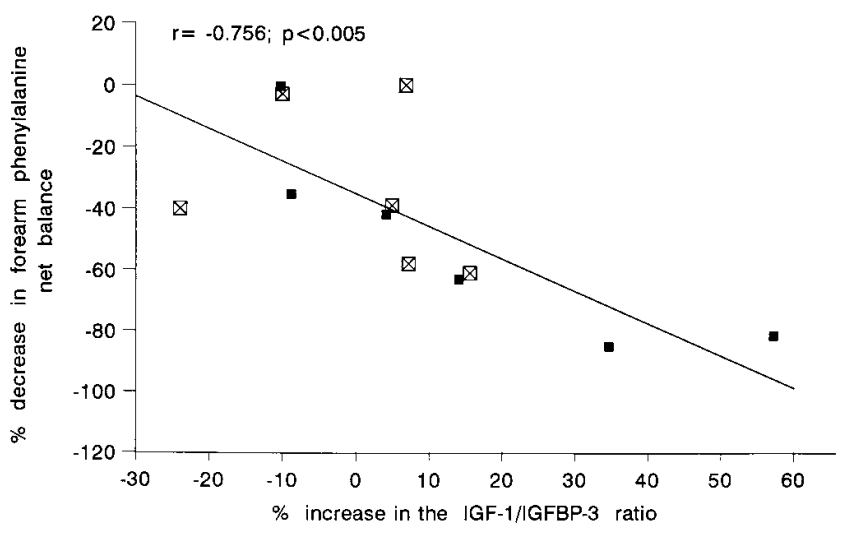

Figure 5. The percent decrease over basal values in forearm phenylalanine net balance vs. the percent increase in the IGF-I/IGFBP-3 ratio in malnourished HD patients in the postabsorptive state during

(ם) and after rhGH administration $(\nabla)$. The decrease in forearm phenylalanine net balance was inversely correlated with the increase in the IGF-I/IGFBP-3 ratio, with greatest decreases observed with highest circulating IGF-I/IGFBP-3 ratios.

the forearm and, five of them, increased plasma potassium concentrations (Table V). After rhGH, plasma potassium concentrations declined in five cases and remained unchanged in one. At the same time the release of potassium from the forearm declined. During the three periods of the study plasma potassium concentrations were directly related to potassium release from the forearm (Fig. 6). Moreover, the release of potassium from the forearm was directly related to net protein balance and the rate of disposal of phenylalanine (Fig. $7 A$ and $B$ ). Forearm potassium release was not related to insulin, cortisol, IGF-I, IGFBP-1, or IGFBP-3 levels.

\section{Discussion}

The present study demonstrates that the administration of rhGH to malnourished hemodialysis patients significantly increases muscle protein synthesis but has no effect on muscle protein degradation. In our patients the augmentation of protein synthesis led to a diminished muscle protein loss, as shown by the reduction in the net forearm phenylalanine balance and the decrease in the net forearm amino acid output. The changes induced by the administration of $\mathrm{rhGH}$ were reversed by rhGH discontinuation.

Baseline rates of appearance and disposal of phenylalanine measured in this group of malnourished patients are about $30 \%$ lower than those measured in well nourished CRF patients under unrestricted diets $(4,29)$ and are also in the lower range of the values recorded in normal subjects in the litera-

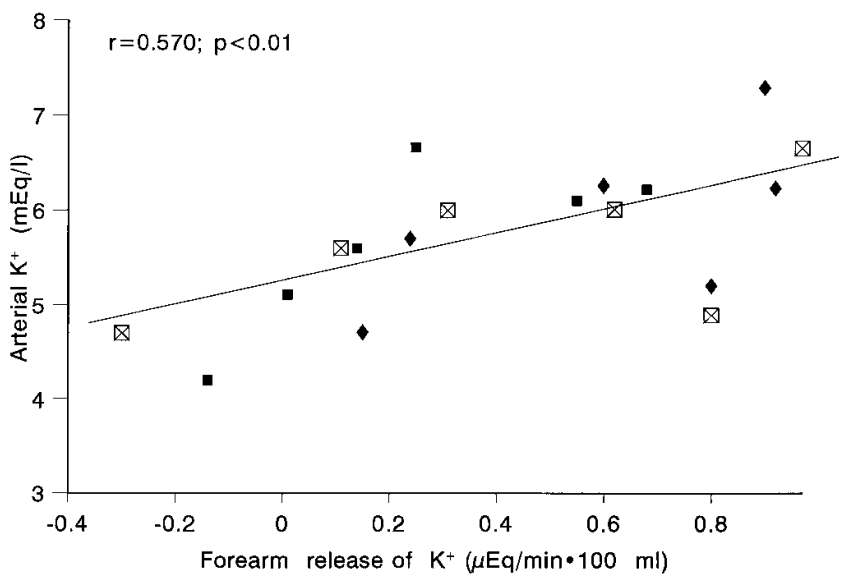

Figure 6. Relationship between plasma potassium levels and forearm potassium release in malnourished hemodialysis patients before $(\bullet)$, during ( $\square)$, and after $(\nabla)$ rhGH administration.

ture $(23,30)$ and in our laboratory (4). This observation suggests that low rates of protein synthesis occur in the muscle of malnourished HD patients and is in accordance with studies showing a decrease in RNA/DNA ratio in muscle in such patients (31). A decrease in protein synthesis could by itself promote muscle wasting. Moreover, reduced rates of protein synthesis are believed to hinder body response to stress. Accordingly, strategies to increase muscle protein turnover could improve muscle protein metabolism and nutrition in malnourished dialysis patients. However, current therapeutic strategies for reversing malnutrition are often unsuccessful (21).

A few observations suggest that rhGH could play a role in the treatment of malnourished renal patients, despite resistance to rhGH and IGF-I actions in uremia. rhGH treatment results in a decrease in urea generation $(19,20)$, as well as, when combined with parenteral nutrition, in an increased albumin and transferrin concentration (20). Similar results have been obtained after 7-d rhGH treatment in uremic patients undergoing peritoneal dialysis (22). However, these observations are limited to the study of a few biochemical parameters, while the effects of rhGH on muscle protein kinetics have never been examined.

The mechanism(s) by which rhGH mediates its anabolic effects on muscle is (are) not yet completely understood. rhGH causes net anabolism in humans through an increase in protein synthesis both in the whole body $(32)$ and in muscle $(33,34)$. rhGH infused acutely into the brachial artery stimulates protein synthesis (35). The improvement in forearm protein balance is not associated with changes in systemic $\mathrm{GH}$, insulin, or IGF-I, indicating that the anabolic effects are due to GH per se

Table V. Plasma Levels of Potassium and Forearm Potassium Release at the Baseline, during GH treatment and in Washout Period

\begin{tabular}{lccc}
\hline & Baseline & GH treatment & Washout \\
\hline Arterial K $(\mathrm{meq} /$ liter) & $6.0 \pm 0.37$ & $5.5 \pm 0.35$ & $5.6 \pm 0.37$ \\
$\mathrm{~K}^{+} \mathrm{A}-\mathrm{V}$ difference $(\mathrm{meq} / \mathrm{liter})$ & $-0.301 \pm 0.77^{*}$ & $-0.134 \pm 0.078^{\ddagger}$ & $-0.212 \pm 0.058$ \\
Forearm K net balance $(\mu \mathrm{eq} / \mathrm{min})$ & $-0.60 \pm 0.15$ & $-0.24 \pm 0.13^{\ddagger}$ & \\
$\mathrm{K}^{+}$net balance & & & \\
\multicolumn{1}{l}{ Phe net balance $(\mu \mathrm{eq} / \mathrm{nmol})$} & $0.039 \pm 0.01$ & $0.032 \pm 0.03$ & $0.035 \pm 0.02$
\end{tabular}

Probability that $\mathrm{A}-\mathrm{V}$ difference does not differ from $0:{ }^{*} P<0.02$. Significance of difference from baseline value: ${ }^{\ddagger} P<0.03$. 

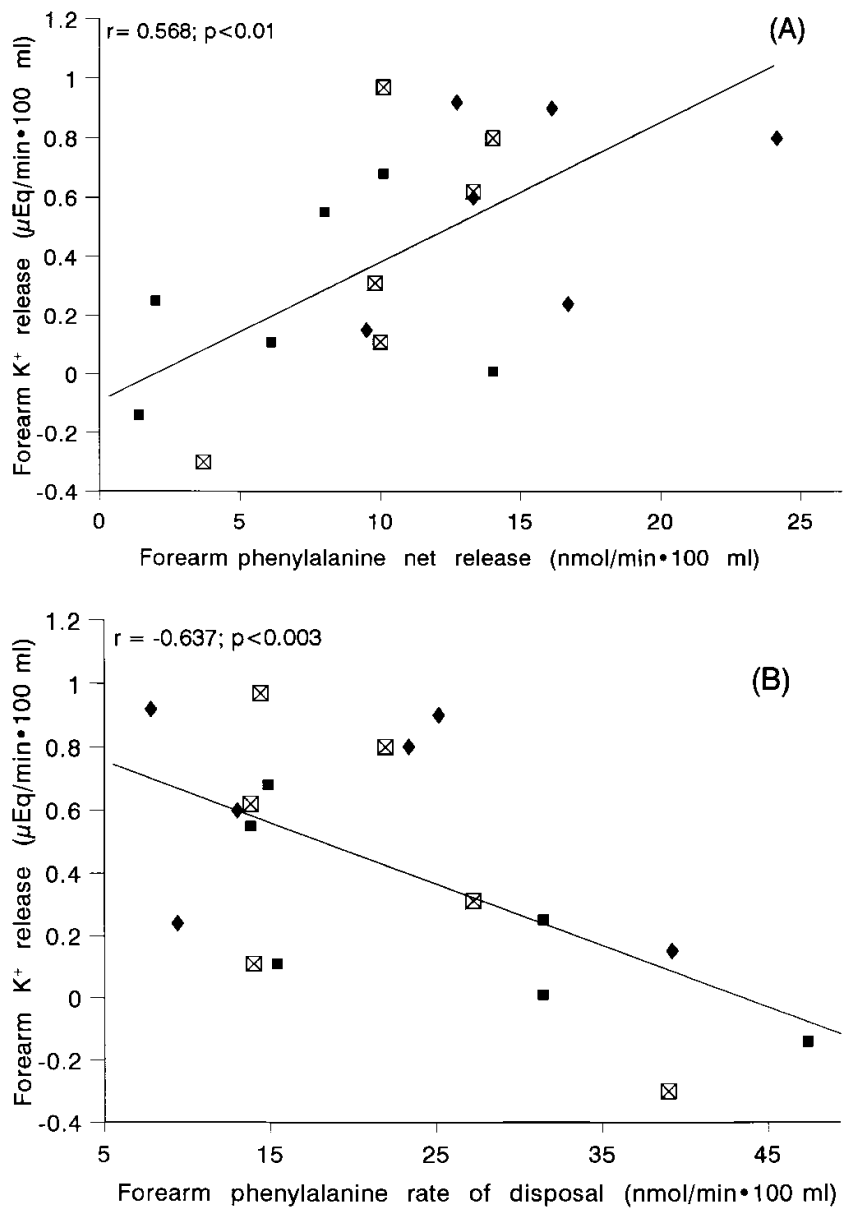

Figure 7. Relationships between the forearm release of potassium and the net phenylalanine release $(A)$ and the phenylalanine rate of disposal $(B)$ in malnourished hemodialysis patients before $(\diamond)$, during $(\boldsymbol{\square})$, and after $(\boldsymbol{\nabla}) \mathrm{rhGH}$ administration.

or via local IGF-I (35). However, it has also been suggested that the protein anabolic effects of acute rhGH administration may be nonhomogeneous in muscle and nonmuscle tissues, on the grounds that an increase in whole body protein synthesis without a concomitant increase in muscle protein synthesis has also been observed (36). It is possible that many of the anabolic effects of rhGH on body tissues observed in chronic studies are mediated via the stimulation of endogenous IGF-I synthesis, which may exert its effects via endocrine and/or paracrine mechanisms. In humans, IGF-I, like insulin, promotes whole body anabolism by inhibiting protein degradation (37), though an increase in protein synthesis has also been observed (38). When infused intraarterially into healthy volunteers, IGF-I has been shown to exert both GH-like effects, (increase in protein synthesis), and insulin-like effects, (inhibition of protein degradation), in forearm muscle (39). It has been suggested that the extent of IGF-I binding, rather than total serum IGF-I levels per se, is predictive of the IGF-I metabolic effects (39). In normal subjects the main form of circulating IGF is the GH-dependent ternary complex of $140 \mathrm{kD}$ consisting of the IGF peptide, IGFBP-3, and an acid-labile glycoprotein subunit (ALS). Another IGF-IGFBP complex of 40-50 $\mathrm{kD}$ can be identified in adult humans and consists of a mixture of binary complexes between the IGF peptide and IGFBP-1 to 6 (11). The majority of circulating IGF-I is bound to IGFBP-3; however, because of its rapid changes in serum concentration, IGFBP-1 is also assumed to modulate the free fraction of IGF-I (40). It is interesting that chronic GH administration not only increases total IGF-I levels, but also the free IGF-I fraction, because rhGH suppresses circulating IGFBP-1 and IGFBP-2, and increases IGFBP-3 to a lesser extent than IGF-I (41).

The present study shows that in malnourished renal patients the changes in circulating IGF-I and IGFBPs during GH therapy are associated with a reduction in the negative muscle protein balance observed in the postabsorptive state. In our patients, baseline levels of IGFBP-1 were increased sixfold, in accordance with previous studies in renal patients (41). After rhGH, serum IGF-I increased by $36 \%$ and this rise was associated with a less prominent increase in IGFBP-3 levels and, particularly, with a decrease in IGFBP-1. At the same time muscle protein synthesis increased by $25 \%$ and net protein balance declined by $47 \%$. The decline in net protein balance was not related with total IGF-I levels. However, as shown by stepwise multiple regression analysis, the percent increase in the IGF-I/IGFBP-3 ratio accounted for a substantial proportion of variations in net protein balance, thus suggesting that the amount of IGF-I free from ligand binding with IGFBPs is responsible for the decreased muscle net protein catabolism. Another considerable proportion of changes in net protein balance was accounted for by the decrease in IGFBP-1 after $\mathrm{rhGH}$. This protein is produced by the liver and both insulin (42) and rhGH (41) reduces IGFBP-1 levels, thus increasing the bioavailability of IGF-I.

In the present study, $\mathrm{rhGH}$ administration for $6 \mathrm{wk}$ failed to increase the reduced circulating levels of many essential amino acids, including branched-chain amino acids (BCAA). On the other hand, the forearm release of leucine was markedly diminished during rhGH administration; this is in line with the GH-related effects of reducing leucine oxidation and increasing the use of leucine for protein synthesis (32). The diminished muscle production of BCAA was probably accompanied by a reduced utilization by other organs, in order to keep their circulating levels unchanged. A preeminent extramuscle effect of rhGH can also be taken into account for results regarding glutamate. rhGH administration promoted an increase in arterial glutamate, despite a tendency for its muscle balance to become more positive. In rats, $\mathrm{GH}$ has been shown to markedly reduce liver glutamate uptake and to increase glutamate levels, thus reducing ureagenesis (43).

A unique behavior was observed for cyst(e)ine. Baseline cyst(e)ine levels were elevated in the CRF patients studied here, in accordance with previous findings (44). In renal patients there is a decreased fractional uptake of this amino acid by muscle, as previously shown in our laboratory (45). Therefore, a deranged metabolism or transport of cyst(e)ine by muscle may be responsible for its increase in blood. During rhGH treatment the muscle fractional uptake of cyst(e)ine increased to normal values and the blood levels of cyst(e)ine declined; moreover, these changes were reversed by rhGH discontinuation. These data indicate that rhGH positively affects muscle cyste(i)ne transport and/or metabolism in uremic patients.

In the postabsorptive period, as well as in fasting subjects, a gradual release of potassium from peripheral tissues (46) is offset by an excretion of potassium by the kidney. In patients with ESRD, given their negligible renal excretion of potassium, ex- 
trarenal potassium metabolism assumes a critical role in potassium homeostasis. However, several observations have indicated an impairment of extrarenal potassium metabolism occurring in CRF (47). Somatostatin administration to fasting rats is followed by a greater increase in plasma potassium in uremic than in normal animals (48). Moreover, the ouabaininhibitable rubidium uptake by skeletal muscle from uremic rats is impaired (49). These observations in animals are in agreement with clinical studies, and show that fasting is followed by a rise in serum potassium in dialysis patients, but not in controls (50). Moreover, in hemodialysis patients, a potassium load induces an increase in plasma potassium which is greater than in controls and which is not accounted for by renal excretion (51). In postabsorptive patients studied here plasma potassium levels were directly related to forearm muscle potassium release. Such an observation underlines the role of potassium release from peripheral tissues in determining postabsorptive potassium plasma levels in ESRD patients. The present study also indicates that the administration of rhGH to malnourished HD patients promotes a reduction in the negative forearm potassium balance observed in the postabsorptive state, complementing the anabolic effects on protein turnover. That $\mathrm{GH}$ participates in potassium metabolism regulation has been suggested by many studies (52). Acute administration of $\mathrm{GH}$ in humans induces an increase in potassium uptake by the forearm (53). The effects on the forearm uptake of potassium are more immediate than those on muscle protein metabolism (30 min vs. $6 \mathrm{~h} ; 53,35)$, thus indicating that rhGH may exert a specific effect on the transport of potassium in muscle. On the other hand, in GH-deficient patients, rhGH treatment increases both muscle mass and whole body by $40 \mathrm{~K}$ (54), but the increase in whole body potassium seems to reflect an increased lean body mass rather than an intracellular accumulation of potassium (54). In ESRD patients under peritoneal dialysis (CAPD) short-term rhGH admistration reduces both plasma potassium and phosphorus, thus suggesting incorporation into somatic proteins (22). The relations between potassium and protein turnover are not completely understood. Studies in vitro have shown that potassium is necessary for protein synthesis to occur (55). In rats the incorporation of leucine into mixed muscle proteins is reduced by feeding a potassium-deficient diet (56). On the other hand, potassium and proteins in skeletal muscle are strongly correlated because intracellular proteins interact with potassium by electrostatic binding (57). The effects of rhGH on muscle potassium metabolism could theoretically be due to a specific action of rhGH on potassium transport or be nonspecifically related to a more anabolic state. In the present study forearm potassium release was related both to the rate of muscle protein synthesis and to net protein balance. Moreover, the ratio of potassium release to net protein balance was similar before and after rhGH. Accordingly, the results of the present study indicate that the reduced release of potassium by muscle after $\mathrm{GH}$ is accounted for by a lessened catabolic condition and not by an intracellular potassium accumulation per se.

An estimate of the effects on muscle mass accretion during rhGH treatment may be offered by the changes in forearm phenylalanine net balance. Considering that the mean fraction of forearm made up of muscle tissue is about 0.6 (58), that forearm blood flow in forearm muscle is about $70 \%$ of total flow (58), that muscle is on the average $40 \%$ of body weight, that phenylalanine is about $4-5 \%$ of actin composition (59), and that muscle is composed by $20 \%$ proteins, the change in net phenylalanine release from the forearm after rhGH would account for a less negative muscle balance of about $18-20 \mathrm{~g} / \mathrm{d}$. This is in keeping with an increase in muscle mass of about 20 $\mathrm{g} / \mathrm{d}$ observed in $\mathrm{GH}$-deficient patients during $\mathrm{GH}$ repletion therapy (54).

In the present study, no untoward effects were noted during rhGH administration, but it is possible that exacerbation of glucose intolerance and hyperlipidemia could occur with more prolonged therapies at the doses employed. Although we did not specifically address these issues, rhGH administration in the present study did not result in any significant change in basal glucose and insulin levels. Our observations suggest that uremic patients with moderate-advanced malnutrition are quite responsive to $\mathrm{rhGH}$ and that the rhGH-associated changes in circulating unbound IGF-I and IGFBPs are the mediators for the response. However, blood IGF-I concentrations and/or activity do not always increase following rhGH administration in severely malnourished patients with low intakes of calories and/or proteins (14).

In summary, the present study shows that rhGH treatment in chronic malnourished HD patients is followed by an increase in muscle protein synthesis and by a decrease in the negative muscle protein and potassium balance observed in the postabsorptive state. The anabolism obtained with rhGH can be accounted for by the associated changes in circulating free, but not total, IGF-I levels. These observations also suggest that the resistance to GH occurring in malnourished HD patients can be overcome by treatment with pharmacologic doses of this hormone.

\section{Acknowledgments}

The authors thank Dr. A. Miola and Pharmacia Metabolic Diseases, Milan, Italy for kindly providing rhGH. The authors thank also Mrs. M.S. Sala and Mr. M. Marchelli for their technical assistance and Mrs. F. Tincani for the preparation of manuscript and figures.

This study was supported by grants from the Ministero dell' Università e della Ricerca Scientifica e Tecnologica (Assegnazione per la ricerca scientifica $40 \%$ ) and by a grant from the National Research Council (CNR)-Targeted project, Prevention and Control Disease Factors; Subproject Sp1 Alimentazione.

\section{References}

1. Bergstrom, J. 1996. Nutrition and mortality in hemodialysis. J. Am. Soc. Nephrol. 6:1329-1341.

2. Reaich, D., S.R. Price, B.K. England, and W.E. Mitch. 1995. Mechanisms causing muscle loss in chronic renal failure. Am. J. Kidney Dis. 26:242-247.

3. Price, S.R., B.K. England, J.L. Bailey, K. Van Vreede, and W.E. Mitch. 1994. Acidosis and glucocorticoids concomitantly increase ubiquitin and proteasome subunit mRNAs in rat muscle. Am. J. Physiol. 267:C955-C960.

4. Garibotto, G., R. Russo, A. Sofia, M.R. Sala, C. Robaudo, P. Moscatelli, G. Deferrari, and A. Tizianello. 1994. Skeletal muscle protein synthesis and degradation in patients with chronic renal failure. Kidney Int. 45:1432-1439.

5. Lim, V.S., D.M. Bier, M.J. Flanigan, and S.T. Sum-Ping. 1993. The effect of hemodialysis on protein metabolism. A leucine kinetic study. J. Clin. Invest. 91:2429-2436.

6. Chan, W., C.V. Kristoffer, and J.C.M. Chan. 1993. Expression of insulinlike growth factor-1 in uremic rats: Growth hormone resistance and nutritional intake. Kidney Int. 43:790-795.

7. Tonshoff, B., S. Edén, E. Weiser, B. Carlsson, I.C.A.F. Robinson, W. Blum, and O. Mehls. 1994. Reduced hepatic growth hormone $(\mathrm{GH})$ receptor gene expression and increased plasma $\mathrm{GH}$ binding protein in experimental uremia. Kidney Int. 45:1085-1092.

8. Kopple, J.D., H. Ding, and X.L. Gao. 1995. Altered physiology and action of insulin-like growth factor-1 in skeletal muscle in chronic renal failure. Am. J. Kidney Dis. 26:248-255. 
9. Ding, H., X.L. Gao, R. Hirschberg, J.V. Vadgama, and J.D. Kopple. 1996. Impaired actions of Insulin-like Growth Factor 1 on protein synthesis and degradation in skeletal muscle of rats with chronic renal failure. Evidence for a postreceptor defect. J. Clin. Invest. 97:1064-1075.

10. Haffner, D., F. Schaefer, J. Girard, E. Ritz, and O. Mehls. 1994. Metabolic clearance of recombinant human growth hormone in health and chronic renal failure. J. Clin. Invest. 93:1163-1171.

11. Krieg, R.J., F. Santos, and J.C.M. Chan. 1995. Growth hormone, insulin like growth factor and the kidney. Kidney Int. 48:321-326.

12. Fouque, D., S. Peng, and J.D. Kopple. 1995. Pharmacokinetics of recombinant human insulin-like growth factor-1 in dialysis patients. Kidney Int. 47:851-857.

13. Phillips, L.S., A.C. Fusco, T.G. Unterman, and F. Del Greco. 1994. Somatomedin inhibitor in uremia J. Clin. Endocrinol. Metab. 59:764-772.

14. Thyssen, P., J.M. Ketelslegers, and L.E. Underwood. 1994. Nutritional regulation of the insulin-like growth factors. Endocr. Rev. 15:80-101.

15. Manson, J.M., and D.W. Wilmore. 1986. Positive nitrogen balance with human growth hormone and hypocaloric intravenous feeding. Surgery (St. Louis). 100:188-197.

16. Salomon, F., R.C. Cuneo, R. Hesp, and Sonksen P.H.. 1989. The effects of treatment with recombinant human growth hormone on body composition and metabolism in adults with growth hormone deficiency. N. Engl. J. Med. 321: 1797-1803.

17. Forbes, G.B. 1988. Body composition: influence of nutrition, disease, growth and aging. In Modern Nutrition in Health and Disease. M.E. Shils and V.R. Young, editors. 7th ed. Lea and Febiger, Philadelphia. 533-556.

18. Fine, R.N., K. Pyke-Grimm, and P.A. Nelson. 1991. Recombinant human growth hormone treatment of children with chronic renal failure: longterm (1 to 3 year) outcome. Pediatr. Nephrol. 5:477-481.

19. Ziegler, T.R., J.M. Lazarus, L.S. Young, R. Hakim, and D.W. Wilmore. 1991. Effects of recombinant growth hormone in adults receiving maintenance hemodialysis. J. Am. Soc. Nephrol. 2:1130-1135.

20. Schulman, G., R.L. Wingard, R.L. Hutchinson, P. Lawrence, and R.M. Hakim. 1993. The effects of recombinant human growth hormone and intradialytic parenteral nutrition in malnourished hemodialysis patients. Am. J. Kidney Dis. 21:527-534.

21. Kopple, J.D. 1992. The rationale for the use of growth hormone or insulin-like growth factor-I in adult patients with renal failure. Miner. Electrolyte Metab. 18:269-275.

22. Ikizler, T.A., R. Wingard, J. Breyer, G. Schulman, R. Parker, and R. Hakim. 1994. Short-term effects of recombinant human growth hormone in CAPD patients. Kidney Intern. 46:1178-1183.

23. Gelfand, R.A., and E.J. Barrett. 1987. Effect of physiological hyperinsulinemia on skeletal muscle protein synthesis and breakdown in man. J. Clin. Invest. 80:1-6.

24. Metropolitan Life Foundation. 1983. Metropolitan height and weight tables. Stat. Bull. Metrop. Life Insur. Co. 64:2-17.

25. Borah, M.F., P.Y. Schoenfeld, F.A. Gotch, J.A. Sargent, M. Wolfson, and M.H. Humphreys. 1978. Nitrogen balance during intermittent dialysis therapy of uremia. Kidney Int. 14:491-500.

26. Tizianello, A., G. Deferrari, G. Gurreri, G. Garibotto, and C. Robaudo. 1980. Renal metabolism of amino acids and ammonia in subjects with normal renal function and in patients with chronic renal insufficiency. J. Clin. Invest. 65: 1163-1173.

27. Doughaday, W.H., I.K. Martz, and S.L. Blethen. 1980. Inhibition of access of bound somatomedin to membrane receptor and immunoglobulin sites: a comparison of radioreceptor and radioimmunoassay of somatomedin in native and acid-ethanol extracted serum. J. Clin. Endocrinol. Metab. 19:781-788.

28. Garibotto, G., G. Deferrari, C. Robaudo, S. Saffioti, M.R. Sala, E. Paoletti, and A. Tizianello. 1991. Effects of a new amino acid supplement on blood amino acid pools in patients with chronic renal failure. Amino Acids (Vienna). 1:319-329.

29. Garibotto, G., R. Russo, A. Sofia, C. Robaudo, P. Araghi, G. Deferrari, and A. Tizianello. 1995. Protein intake and muscle protein turnover in chronic renal failure patients. J. Am. Soc. Nephrol. 6:388. (Abstr)

30. Louard, R.J., D.A. Fryburg, R.A. Gelfand, and E.J. Barret. 1992. Insulin sensitivity of protein and glucose metabolism in human forearm skeletal muscle. J. Clin. Invest. 90:2348-2354.

31. Guarnieri G., G. Toigo, R. Situlin, L. Faccini, U. Colli, S. Landini, G. Bazzato, F. Dardi, and L. Campanacci. 1983. Muscle biopsy studies in chronically uremic patients: Evidence for malnutrition. Kidney Int. 24 (Suppl. 16): S187-S193.

32. Horber, F.F., and M.W. Haymond. 1990. Human growth hormone prevents the catabolic side effects of prednisone in humans. J. Clin. Invest. 86:265272.

33. Fryburg, D.A., and E.J. Barret. 1993. Growth hormone acutely stimulates skeletal muscle but not whole body protein synthesis in humans. Metab. Clin. Exp. 42:1223-1227.

34. Fryburg, D.A., R.A. Gelfand, and E.J. Barrett. 1991. Growth hormone acutely stimulates forearm muscle protein synthesis in normal humans. Am. J.
Physiol. 260 (Endocrinol. Metab. 23):E499-E504.

35. Fryburg, D.A., R. Louard, K. Gerow, R. Gelfand, and E. Barret. 1992. Growth hormone stimulates skeletal muscle protein synthesis and antagonizes insulin's antiproteolytic action in humans. Diabetes. 41:424-429.

36. Copeland, K.C., and K.S. Nair. 1994. Acute growth hormone effects on amino acid and lipid metabolism. J. Clin. Endocrinol. Metab. 78:1040-1047.

37. Laager, R., R. Ninnis, and U. Keller. 1993. Comparison of the effects of recombinant human insulin-like growth factor-1 and insulin on glucose and leucine kinetics in humans. J. Clin. Invest. 92:1903-1909.

38. Mauras, N., and B. Beaufrère. 1995. Recombinant human insulin-like factor-I enhances whole body protein anabolism and significantly diminishes the protein catabolic effects of prednisone in humans without a diabetogenic effect. J. Clin. Endocrinol. Metab. 80:869-874.

39. Fryburg, D.A. 1994. Insulin-like growth factor-1 exerts growth hormone- and insulin-like actions on human muscle protein metabolism. Am. J. Physiol. 267:E331-E336.

40. Lee, P.D.K., C.A. Conover, and D.R. Powell. 1993. Regulation and function of insulin-like growth factor-binding protein-1. Proc. Soc. Exp. Biol. Med. 204:4-29.

41. Hokken-Koelega, A.C.S., T. Stijnene, S.M.P.F. de Muinck KaizerSchrama, J.M. Wit, E.D. Wolff, M.C.J.W. De Jong, R.A. Donckerwolcke, N.C.B. Abbad, A. Bot, W.F. Blum, et al. 1991. Placebo-controlled, doubleblind, cross-over trial of growth hormone treatment in prepurbertal children with chronic renal failure. Lancet. 338:585-590.

42. Brismar, K., E. Fernqvist-Forbes, J. Wahren, and K. Hall. 1994. Effect of insulin on the hepatic production of insulin-like growth factor-binding protein-1 (IGFBP-1), IGFBP-3, and IGF-I in insulin-dependent diabetes. J. Clin. Endocrinol. Metab. 79:872-878.

43. Welbourne, T., S. Joshi, and R. McVie. 1989. Growth hormone effects on hepatic glutamate handling in vivo. Am. J. Physiol. 257:E959-E962.

44. Tizianello, A., G. Deferrari, G. Garibotto, C. Robaudo, S. Saffioti, and E. Paoletti, 1988. Abnormalities of amino acid and keto acid metabolism in chronic renal failure. In Nephrology. A.M. Davison, editor. Baillère-Tindall, London. 1011-1025.

45. Deferrari, G., G. Garibotto, C. Robaudo, A. Canepa, S. Bagnasco and A. Tizianello. 1985. Leg metabolism of amino acids and ammonia in patients with chronic renal failure. Clin. Sci. (Lond.). 69:143-151.

46. Anders, R., M.A. Baltzan, G. Cader, and K. Zierler. 1962. Effect of insulin on carbohydrate metabolism and on potassium in the forearm of man. $J$. Clin. Invest. 41:108-115.

47. Allon, M. 1995. Hyperkalemia in end-stage renal disease: mechanisms and management. J. Am. Soc. Nephrol. 6:1134-1142.

48. Goecke, I.A., S. Bonilla, E.T. Marusic, and M. Alvo. 1991. Enhanced insulin sensitivity in extrarenal potassium handling in uremic rats. Kidney Intern. 39:39-43.

49. Bonilla, S., I.A. Goecke, S. Bozzo, M. Alvo, L. Michea, and E.T. Marusic. 1991. Effect of chronic renal failure on NA-K ATP-ase alpha-1 and alpha-2 mRNA transcription in rat skeletal muscle. J. Clin. Invest. 88:2137-2141.

50. Allon, M., A. Takeshian, N. Shanklin. 1993. Effect of insulin plus glucose infusion with or without epinephrine on fasting hyperkaliemia. Kidney Intern. 43:212-217.

51. Allon, M., L. Dansby, and N. Shanklin. 1993. Glucose modulation of the disposal of an acute potassium load in patients with end-stage renal disease. Am. J. Med. 94:475-482.

52. Perrone, R.D., and E.A. Alexander. 1994. Regulation of extrarenal potassium metabolism. In Maxwell and Kleeman's Clinical Disorders of Fluid and Electrolyte Metabolism. R.G. Narins, editor. Mac Graw-Hill Inc., New York. 129-145.

53. Zierler, K.L., and D. Rabinovitz. 1963. Roles of insulin and growth hormone, based on studies of forearm metabolism in man. Medicine (Baltimore). 42:385-401.

54. Valk, N.K., A.J. Lely, W.W. De Herder, J. Lindemans, and S.W.J. Lamberts. 1994. The effects of human growth hormone administration in GH-deficient adults: a 20-day metabolic ward study J. Clin. Endocrinol. Metab. 79:10701076

55. Cannon, P., L.E. Frazier, and R. Hughes. 1951. Influence of potassium on tissue protein synthesis. Metab. Clin. Exp. 1:49-57.

56. Alexis, S.D., G. Vilaire, and V. Young. 1971. Cell-free studies of protein synthesis with skeletal muscle from normal and potassium-depleted rats. $J$. Nutr. 101:273-286.

57. Adrogué, H.J. 1991. Mechanims of transcellular potassium shifts in acidbase disorders. In Nephrology. Proc. XIIth Congr. Intern. Soc. Nephrol. M. Hatano, editor Springer-Verlag New York Inc., New York. 252-261.

58. Yki-Jarvinen, H., A. Young, C. Lamkin, and J. Foley. 1987. Kinetics of glucose disposal in whole body and across the forearm in man. J. Clin. Invest. 79:1713-1719.

59. Clowes, G.H.A., H.T. Randall Jr., and J.C. Chan 1980. Amino acid and energy metabolism in septic and traumatized patients. J. Parenter. Enteral. Nutr. 4:195-205. 